\title{
Investigating the Role and Importance of Persian Crown Jewels in Economic and Political Developments in Shah Abbas I Era $(1587-1629)$
}

\author{
Sayed Mas'ud Sayed Bonakdar ${ }^{1}$, Hussein Mir Ja' fari ${ }^{1} \&$ Loghman Dehghan Niri ${ }^{1}$ \\ ${ }^{1}$ History Department, Isfahan University, Isfahan, Iran \\ Correspondence: Sayed Mas'ud Sayed Bonakdar, History Department, Isfahan University, Iran. Tel: \\ 98-913-129-2376. E-mail: masoudbonakdar@yahoo.com
}

Received: April 17, 2012 Accepted: May 24, 2012 Online Published: July 1, 2012

doi:10.5539/ach.v4n2p146

URL: http://dx.doi.org/10.5539/ach.v4n2p146

\begin{abstract}
From their early history, Persians have always been charmed by jewelry and whenever a powerful dynasty came to power, economy of the country would become more dynamic and a collection of the most precious gems and jewels would be accumulated. The glorious age of the Safavids was not an exception to this. In the reign of Shah Abbas as the greatest Safavid king, the importance of possessing a treasury full of jewels, gold and silver for king's own person made him expand his treasury and jewelry collection more than ever and use it in achieving other political ends during his reign. Using existing resources, this study aims to investigate the role and importance of crown jewels in the economic and political developments in the reign of Shah Abbas I. Library research method and comparison and analysis of existing resources, especially the original resources are used in this article. After necessary data are collected, they are organized and then analyzed and finally conclusions are drawn.
\end{abstract}

Keywords: crown jewels, Shah Abbas, the Safavid era

\section{Introduction}

From the beginning of their history, Persians have been living with various jewelries. The liveliness of the country and people's penchant for a luxurious and splendid living mingled with their high aesthetic feelings have always attracted Iranians to jewelries and gems.

Persians' national epic, The Shahnama, is replete with allusions and passages referring to various gems and jewelries which Persians had discovered and put to use:

$$
\text { هو ياقوت كرد از او روشني خو استار }
$$

$$
\begin{aligned}
& \text { ز خار اگگهر جست يك روز } \\
& \text { به جنح آمدش جند كونه گَّر }
\end{aligned}
$$

Once sought gems from granite, searched for light in it

Gems of many types he gained, such as ruby, topaz, and gold and silver

Using existing resources, this study aims to investigate the role and importance of crown jewels in the economic and political developments in the reign of Shah Abbas I. Using comments by different Iranian and European writers, we intend to show that aside from the known and determining internal and foreign factors, there were other factors such as crown jewels which played a significant role in the politics of the Safavid era.

Emerging of great and powerful empires and creation of magnificent and affluent courts in Persian history led to accumulation of rare and exquisite gems in Iranian treasuries. The glorious age of the Safavids was not an exception to this. The Safavid kings not only endeavored to preserve the jewelries handed down from the past, but also continued to purchase and acquire collections of gemstones, invaluable jewelries and gold and silver collections. They bought gems from India, the Ottoman Empire, Italy and France and brought them to Isfahan to be 
used in unique artifacts. Crown jewels had different roles and positions according to the historical conditions of the time of each king's reign.

When Shah Abbas came to power in 1587, the situation in Iran was chaotic and the royal treasury had become almost empty due to the lavish generosities of Shah Abbas' father and predecessor, Sultan Mohammad, the emirs were busy fighting each other, and foreign forces had violated Iranian boundaries. Shah Abbas set upon resolving these problems. He first started to control the turbulent domestic situation and establish order and security throughout the country. Then he made some changes in the military forces and economic structure of the country. The primary stage of the king's movements was expelling foreign forces that had encroached Persian lands from east and west. The eastern part of the country was attacked by the Uzbeks and the western part by the Ottomans. However, mobilizing the army to defend the country required extensive financial resources which, as mentioned before, were not readily available since Shah Abbas had not inherited a rich treasury. Shortage of financial resources in the treasury of Shah Abbas was so critical that when he decided to invade the Uzbeks who had massacred and oppressed people in Khorasan and the Holy Shrine (The shrine of the Sixth Imam of the Shiites), he was compelled to give out orders to change the royal court dishes into coins.

\section{Review and Analysis}

\subsection{Shah Abbas' Strategic Use of Gold and Jewelries}

Our information about Shah Abbas' using of crown jewelries for his political aims is limited to the writings of Oruj Beyk Bayat, one of the courtiers close to Shah Abbas. In his writings, Oruj Beyk writes about things that historians of Safavid era had avoided writing about because of the restrictions they had. Other contemporary historians preferred to be absolutely silent about the melting of the dishes. In any case, melting down the dishes and transforming them into coins was not a pleasant topic for the historians to write about. And the reason why Oruj Beyk dares to write about this topic is that he had left Iran and its court years before. Therefore, it is highly probable that other instances of changing silverware and gold dishes into coins have occurred about which historians preferred to be silent.

About this act of the Shah, Oruj Beyk explains that when Shah Abbas decided to change his capital city from Qazvin to Isfahan, he heard about the crimes the Uzbeks had done in Khorasan and decided to draw his army to Khorasan, but the treasury was almost empty and mobilizing an army for war was difficult without money. Changing silverware into coins was the solution Shah Abbas had found for this problem. Shah Abbas who was resolute in his decision to move his army into Khorasan, ordered Ishik Aqasi (court affairs supervisor) three times to deliver court dishes to the treasury. But Aqasi repeatedly defied king's order contending that 900,000 Dukas had been spent on the dishes and it would all be wasted. In response, Shah Abbas said, "My father, Sultan Mohammad has said many times that paying sufficient payments before fortune aids us has always led to victory." The king was able to recruit eighty thousand horsemen by melting crown dishes (Bayat, $256 \& 257,1388$ ).

Knowing that possessing a rich treasury could be very helpful in carrying out his plans, Shah Abbas tried to add up to the treasury. Although foreign and Iranian sources have acknowledged the king's simple appearance and clothing, they have written much about the magnificence of his treasury. Shah Abbas was so plain in his appearance and clothing that unlike other kings he was immediately recognized among his commanders and courtiers. If he was seen to be wearing silk garments or aigrette on his Qizilbash crown or on his special hat it was considered uncustomary and his entourage would be surprised (Falsafi, p. 16, 1344, V. 2). Shah Abbas' golden-hilt sword and its leather sheath were the only valuable items he often carried on him (Shirley, p. 150, 1387).

Shah Abbas was aware that for accumulating wealth and using it nothing could be more helpful to the government in critical times than gold and silver; therefore, he did not care for jewelries. He knew that in times of crisis, changing jewelries into coins for dealing with critical situations was difficult and they cannot be used as easily as gold and silver. Thus, Shah Abbas preferred collecting gold and silver to jewelries about which Pietro Della Valle writes, "... [Shah Abbas] is not even interested in jewels. When a European merchant offered him to buy some jewels, Shah Abbas sent him a few guns and some bullets along with the message that "these are my jewels!" (Falsafi, p. 21, v. 4, 1353). With the same belief, when the precious diamond which was stolen from the treasury of the Holy Shrine after the invasion of Uzbeks was returned to the Shrine, Shah Abbas ordered the diamond to be sold and buy some lands for the Holy Shrine (Holy Shrine Document Archive, document no. 44609/01; Eskandar Beyk Turkman, p. 610, v.2, 1382)

Contrarily, however, Shah Abbas was an avid collector of gold and silver. Itinerary writers have written various things about Shah Abbas' fondness for gold. One of these itineraries reports that Shah Abbas I showed interest in the coins the English had minted using minting machine. Better than the high quality minting of the coins, it was their imprint which interested him because he had presumably mistaken the figure of Saint George on the coins 
with that of Imam Ali. The president of the company offered the king 50 coins as a welcoming gesture. But this tribute had a reverse result for the coins were silver and Shah Abbas stated, "it appears that the English government is so miserly that it cannot afford 50 gold coins." In another instance, the English presented Shah Abbas with a grandfather clock which was tested by the treasurer in order to determine and register its karat and weight, but it was found to be gilded and Shah Abbas was offended when he heard about it. The clock was returned straightaway and the English were forced to embellish the clock with golden legs and enamel and present it to Shah Abbas (Tavernier, pp. $481 \& 482,1369$ ).

In this period, there were no cost-effective gold and silver mines in Iran. The available gold and silver were imported via foreign trading. Gold was imported in exchange for products such as silk. Russia was one of the resources of this expensive metal for Iran. The same positive trade balance between Iran and the Ottoman Empire existed between the government and Moscow. In exchange for the goods they purchased, Russians provided export goods such as fur, ironware and some amount of ingot. However, the major portion of these silver and gold ingots and coins were traded to India through Persian Gulf. The main reason for the transfer of big amounts of gold and silver to India was because the largest part of Iran's trading was with the Indian subcontinent. The Safavid government did not produce sufficient export goods to be able to balance the huge amount of spices and goods imported from India. One political representative from the Safavid court in Isfahan describes this situation along these lines: Iran was like an enormous caravansary with two gates; one was the Ottoman side from which European money was transferred to Iran and the other gate was Gombarun port (Bandar Abbas) in the Persian Gulf which was the channel through which money was exported to India (Rudolf, pp. 56-58 \& 63, 1387).

Since minting gold coins in Iran was almost stopped in the middle period of Shah Abbas' reign and no coins were minted till the last decade before the fall of Isfahan during the reign of Shah Sultan Hussein, it was assumed that gold had no important role in the commercial life of the Safavid age. This assumption is rooted in the observations of tourists like Tavernier and Chardin who had wrongly concluded that gold coin was not the currency in Iran and was not available in Safavid markets. Contrary to this enduring belief, not only did gold play an important role in the international transactions, but it also had a high place in the commercial life of the later Safavid era. Although Iranian gold coins were often minted in special situations and were mostly used in the king's accession ceremonies, they circulated extensively in monetary system for they were among the items which were used to be given as gifts (a custom which included large amounts of money) and they were highly demanded by those who intended to go on Hajj or pilgrimages to Shiite shrines in Iraq. Gold was in fact considered as the counterbalance for silver and as an item beyond a mere mercantile object. Gold was extensively used in this period for market regulation and capital saving (Especially in form of Duka coins). Though not Iranian, the gold under discussion has had a very important role in the commercial life of the Safavid era (Ibid, pp. 53, 54 \& 88).

\subsection{Shah Abbas' Tactics for Preserving the Treasury}

Shah Abbas, understanding that marinating gold as capital can help him in critical political and economic situations, took different measures to preserve gold in Iran. In order to prevent gold from being transferred abroad, Shah Abbas ordained some regulations: merchants and travelers had to pay taxes for the gold and silver they carried with them abroad and if they refrained from asserting the amount they carried, the gold and silver detected would be entirely confiscated (Tavernier, p. 138, 1369). As a large amount of money was transferred abroad through Hajj and Holy Shrines (in Iraq) pilgrims Shah Abbas determined to prevent this by transforming Mashhad (an Eastern city of Iran in which there is the burial ground of Imam Reza) into a major Shiite pilgrimage center. Hence, he spent plenty of money on the decorations of the Holy Shrine of Imam Reza in Mashhad (Tavernier, pp. 163 \& 515; Sanson, p. 201, 1346). These expenditures both indicated the Shah's religiousness and his devotion to the Holy Shrine of the eight Shiite Imam and resulted in thriving of Mashhad and thereby fulfilling Shah's commitment in preventing the flowing of money abroad. Therefore, Shah Abbas spent some of the crown jewels and gold on the ornamentation of the Shrine. These rehabilitations seemed to be necessary more than ever after the looting invasion of the Shrine by the Uzbeks (Eskandar Beyk Turkaman, v. 1, p. 413, 1382).

When Shah Abbas arrived in Mashhad and the Holy Shrine after the invasion and looting of the Uzbeks, he found the Shrine ransacked and disorganized with no jewelries and gold and silver ornamentations remaining (Eskandar Beyk Turkaman, p. 568, 1382). He therefore ordered ornate, gold and silver cressets, exquisite chandeliers, Kermani carpets and necessary dishes to be transferred to the shrine (Ibid, v. 2, p. 578). He also ordered the Holy Shrine's dome which had been gilded during the reign of Shah Tahmasp to be completed and a pair of doors decorated with precious gemstones was mounted in the Shrine. In addition, Shah Abbas honored the mausoleums of his ancestors in Ardabil with gifts such jewels and gold from the royal treasury including the gold and silver tombs of Sayyed Jebrail in Ardabil (Husseini Astarabadi, p. 134, 1364; Eskandar Beyk Turkaman, v. 2, p. 1110, 1382; Molla Jalal-udin Monajjem, p. 424, 1366). 
Although it may be assumed that the gold and silver donated to these places were not used by the governments because of the holiness of such places, evidence show that governments would not refrain from exploiting the riches of such places in times of crisis. One proof of this claim is using the savings of the Holy Shrines of Imam Reza and Hazrat-e Ma'suma in Qom for army preparations against the Afghans in the last years of Shah Sultan Hussein's reign.

Another way of saving gold and silver under the direct authority of the king was transforming the existing coins, gold and silver into the dishes usable by the court. Shah Abbas changed a large part of them into dishes and objects such as lighting devices and horse saddles and fittings. In this way, they could be used both as an economic support and as a way to increase the magnificence and greatness of the court. These dishes were used at all occasions and they were not exclusively for special occasions so that the Shah carried them with him in his hunting and long journeys and even in war. The reason for sticking to these dishes was in their very value for the king could use them immediately in critical circumstances. Shah Abbas' passion for increasing his gold inventory is highlighted by the report of a Frenchman who states that people were given money to submit their Dukats to the royal mint where coins were changed into gold dishes: "It was clear that Abbas preferred big golden dishes to tiny coins for it was easier in this way to prevent losing the gold stored in the treasury." (Rudolf, p. 65, 1387). Thomas Herbert also mentions an interesting point in his itinerary and writes that if a golden dish is offered to Shah Abbas as a king, it would be more warmly received if the dish is heavier because he values weight more than the craftsmanship in the dish (Herbert, p. 244, 1928).

Thanks to the numerous foreign itineraries, there is much information about the golden and silver dishes of Shah Abbas' court. According to these itineraries, the majority of the Shah's dishes were gold. All the king's guests were served with the same dishes regardless of their position and rank. These gold and silver dishes included, tray, serving dish cover, wine cups and jug, bowl and finger bowl, flowerpots, etc and other golden and silver utilities such as candlesticks, flambeaux, censer, etc (Molla Jalal-udin Monajjem, p. 442, 1366; Figueroa, pp. 258, 269, 272 \& 338, 1363; Della Valle, pp. 176, 178 \& 188, 1384). Della Valle asserts that not much delicacy and craftsmanship is used in making Shah Abbas' dishes. Apparently, Della Valla was not aware of Shah Abbas' purpose from making those dishes. Della Valle describes a big golden tub used for keeping wine bottles cool and estimates its price to be twenty thousand gold coins. He also writes about small golden wine cups which were deliberately made heavy (Della Valle, p. 274, 1384).

Some of the Shah's dishes were ornate with gold body ornamented with precious gemstones. These ornate dishes included wine jugs and cups which were ornamented with diamond, ruby, emerald, and turquoise (Ibid, pp. 270 \& 273, 1384; Figueroa, 333, 1363). In his itinerary, Shirley estimates the gold and ornate dishes Shah Abbas had carried with him on his trip to the north of Iran to be twenty million liras (Shirley, pp. $149 \& 150,1387$ ).

With his prudence, Shah Abbas took other measures to avoid dispersion and wasting of the wealth and treasury he had acquired during his reign. Thus, in the twenty first year of his leadership he decided to amortize all his movable and immovable properties. These properties which were part inherited and part acquired were valued at around one hundred thousand tomans (Eskandar Beyk Turkaman, v.2, p. 1110, 1382). Shah Abbas had declared that all his properties even his two rings were amortized providing that they be spent on religion and government according to his will (Ibid, v. 2, p. 761). Shah Abbas dedicated his movable properties to different places. He bequeathed his Arabic, juridical, and religious books to the library of the Holy Shrine and sent his Persian books and chinaware to the mausoleum of Sheikh Safy-udin Ardabili, but the destiny of his jewelries, inlaid, gold and silver dishes is unclear. Alam Aray-e Abbasi mentions only Shah Abbas' crown jewels and gold materials and adds, "a purpose is ordained for each one." (Ibid, v. 2, p. 761). But two other sources on the Safavid age, namely Ghesas-ul Khaqani and Tarikh-e Sultani shed more light on the tenor of the deed of endowment in detail and maintain that Shah Abbas endowed all his jewelries, ornate articles and silverware to the Holy Shrine of Imam Ali to be used in building four ornate domes to be placed on the tomb. And about his gold items it was said that when he visits the Holy Shrine, he would personally endow them to be installed in the dome. Ghesas-ul Khaqani in a different version with that of Tarikh-e Sultani contends that the king endowed all his gold and copper items to the mausoleum of Sheikh Safy-udin in Ardabil (Vali Qoli Shamlu, v. 1, p. 194, 1371). Nevertheless, this is not mentioned in any other sources. In the endowment of jewelries it was emphasized that "....if the presiding king touches one single jewelry item or one grain from the gold and silver, it is tantamount to drinking the blood of the Imam." (Ibid, v. 1. p. 194; Husseini Astarabadi, p. 38, 1364). In the same year (1608), Shah Abbas broke some of his ornate daggers and saddles and sent their garnets, rubies, emeralds and other gemstones with Mirza Mohammad, his vizier in Isfahan, to Ali Qoli Khan to be used in building Imam Ali's casket after required gold was procured (Molla Jalal-udin Monajjem, p. 342, 1366; Sa'ad, Bita, p. 204). 
In a letter Shah Abbas wrote to Shah Salim of India, it becomes clear that building the casket of Imam Ali was done with the jewelries Shah Abbas had sent. But due to some unknown reasons, the clergy decided to sell the casket and its jewelries and spend the profits on the religious expenditures of the Shrine. Since Shah Abbas was informed that Shah Salim was eager to buy those jewelries, he notified him that he could dispatch a representative to buy them (Navaii, Shah Abbas' Documents and Correspondences, v. 3, pp. $402 \& 403,1366$ ).

Shah Salim had requested another garnet beside these garnets. This garnet on which names of the ancestors of Shah Salim were incised was among the royal treasury jewelries which Shah Abbas had sent to Najaf. Since this jewel had been bequeathed along with other jewelries to the Shrine, removing it from the shrine required religious authorization. Therefore, after obtaining the clergies' permission, the jewel was put in a precious box and sent to Shah Salim (Falsafi, v. 87, 1344).

The present report is the only one which gives information about the transfer of a part of Shah Abbas' main jewelry to the Shrine of Imam Ali. But no source reports about Shah Abbas' gilding of the dome of Imam Ali's shrine or his endowment of his crown dishes to that place. In the list prepared from Imam Ali's treasury in Nasir-udin Shah's trip to the Holy Shrines in Iraq, 4 gold sconces are mentioned which were gifted by Shah Abbas to the treasury of Imam Ali's Shrine (Nasir-udin Shah, p. 249, 1372).

Apparently, mentioning that Shah Abbas' gold articles and ornate items were bequeathed to the Shrine of Imam Ali was merely for the sake of maintaining the wholeness of the treasury rather than actually transferring them to Najaf. In this way, Shah Abbas could prevent the scattering of his treasury to be transferred generation to generation to the next kings in Safavid dynasty. From other parts of this deed of endowment it is can be inferred that it has been written with the purpose to develop royal lands and properties and add up to and preserve the treasury (Husseini Astar Abadi, p. 138, 1363). The deed of endowment was trusted to the Shah himself according to the content of the deed (Vali Qoli Shamlu, v. 1, p. 196, 1371).

\subsection{Jewelry Sources for the Abbasi Treasury}

Crown jewels in the period of Shah Abbas were collected from various sources. As in the past, the major part of the jewels came from internal and external tributes. The amount of these foreign gifts had considerably increased because of Shah Abbas' political position and his relationship with foreign trade companies. Some part of the inventory of the treasuries was collected from war spoils. But the substantial part of Shah Abbas' jewelries and riches became available through purchases inside the country or by the Shah's middlemen from abroad (Jesuit Fathers Documents, p. 87, 1383). Jewelry trade thrived under the security Shah Abbas established in the country.

Among the many sources which contributed to the accumulation of in-kind and in-cash reserves of the royal treasury were gifts and tributes sent to the Safavid Shah by the kings and leaders of foreign countries. The gifts exchanged accounted for some part of the items going in and out of the treasury.

The custom of receiving a gift was so important in Iran that when a king received a tribute he exhibited in public (Della Valle, p. 185, 1384). Through this exhibition, the Shah showed both the respect representatives of foreign countries had toward the Persian court and embarrassed those representatives who had sent trifle gifts to the court.

Shah Abbas tried to look indifferent when he received gifts especially gold and jewelry. Italian traveler, Della Valle, writing about this habit of Shah Abbas states that the Shah ignored jewelries, gold and silverware and exquisite textiles in appearance, but inwardly he became overjoyed when he received such items and if he was not really interested in war and hunting gears he pretended to be interested in order to make people believe him to be so (Della Valle, p. 187, 1384). But contrary to this habit of the king, court agents were ordained "to hand out every piece of gold and precious item to every person..." so that items would be better exhibited (Falsafi, v. 3, p. 276, 1344).

Being aware of the importance of gifts for Shah Abbas, representatives of foreign nations tried to offer invaluable gifts including precious items such as gold and jewelries to the Shah.

Among other gifts offered by Don Garcia de Silva y Figueroa sent by King Philip III of Spain, there were gold and jewelries which included some gold items and silverware, crystals and other precious jewelries (Figueroa's Itinerary, pp. 262 \& 263, 1363; Della Valle, pp. 248 \& 249; 1384).

In the age of Shah Abbas, the most exquisite gifts were exchanged between Persian and Indian governments. The main part of those gifts consisted of precious gemstones, inlaid items and ornate weapons (Della Valle, pp. 340 \& $341,1384)$. The considerable amount of jewelries exchanged between the two countries well indicates that jewelries acted as an important instrument in their political relations for showing respect and friendship to the other party. Most of the exchanges occurred between Shah Abbas and Shah Salim (Shah Abbas' Documents and Correspondences, p. 388, 1366). Even in the case of the conquest of Kandahar (a city which was the cause of 
dispute between the two nations), Shah Abbas, in order to prevent further antagonisms between the two courts, ordered two big keys be made out of pure gold from the royal treasury with the word of Kandahar inscribed on one key and the word of Iran on the other one. Then, he sent both keys as a sign of friendship to Shah Salim's court (Husseini Astar Abadi, p. 219, 1364).

Great chiefs and governors of different Iranian states had to send souvenirs, tributes and gifts to the king every year in different occasions such as Noruz or other national holidays, when the king had achieved a great victory or when he had honored them with a robe or other gifts.

Shah Abbas often exhibited the gifts great Iranian governors and commanders had sent to him in the presence of the Indian, Ottoman or European ambassadors and messengers to show them the wealth and power of his subordinates and their respect, affection and submission to his own person. Even if the tribute sent by governors was not worthy enough, he would secretly add something precious to it from the royal treasury to make it flaunt in front of foreigners. Giving presents was the panacea of all problems and oftentimes when a governor or commander became victim to the wrath of the Shah, they would mollify him by offering some cash or jewelries (Falsafi, v. 4, pp. $284 \& 288,1344$ ). Therefore, each governor tried to present the king with a more precious gift than the next one. Among the gifts by governors, gifts from Imamqoli Khan, the governor in chief of Fars were among the most expensive. In 1619, he sent gifts to Shah Abbas which included six or seven camel loads of trunks full of precious gemstones (Falsafi, v. 4, p. 285, 1344).

In his description of Imamqoli Khan's presents, Thomas Herbert writes, “....these presents included fifty casks full of pure gold, seventy two casks full of silver and silver coins equal to 465000 Florens which had been loaded on fifty precious valuable camels...in return, the king sent him fifty beautiful Arab horses, 6 suites of exquisite jackets and an ornate sword" (Herbert, p. 226, 1928).

As reported in Herbert's itinerary, in response to the presents he received, the Shah in order to show his favor, sent jewelries along with robes. These jewelries included ornate sword, dagger inlaid with gems, ornate saddle and harness, aigrette decorated with gems, and inlaid dishes among other presents which were given from the collection of crown jewelries. Numerous instances of such grants are observed in the sources related to the period of Shah Abbas (Molla Jalal-udin Monajjam, pp. 223 \& 299, 1366; Eskandar Beyk Turkaman, v. 2, pp. 68, 706 \& 781, 1382; Qazi Ahmad-al Husseini-al Qomi, v. 2, p. 887, 1383; Vali Qoli Shamlu, v. 1, p. 324, 1371). These gifts were sometimes granted to poets to whom Shah Abbas gave gold equal to their weight (Eskandar Beyk Turkaman, v. 2, p. 516, 1382).

Another source which added up to the inventory of the royal treasury in Shah Abbas' period was war spoils. One fifth of the spoils belonged to the king. A large part of these spoils included gold and jewelries. For instance, one of the spoils which had come into the hands of Shah Abbas from the treasury of Lar Sultan "was one piece of crown ornamented with pearl and ruby known as Keykhosrowian Crown which they had inherited from their ancestors" (Ibid, v. 2, pp. 618 \& 705, 1382; Figueroa, p. 95, 1363; Molla Jalal-udin Monajjem, p. 297, 1366).

\section{Conclusion}

To sum all of the points above, Shah Abbas tried, because of the importance of crown jewels in domestic and foreign politics and economy, to add up to the treasury in various ways and attempted to maintain and protect the treasury so that it could saved as a political and economic support for his successors.

Crown jewels were used in foreign relations in different forms. The typical usage was exchange of gifts as an instrument of showing friendship between Iran and other nations. In domestic context, governors and emirs tried to win the favor of the king by presenting him with jewelries and precious items. In return, the king tried to gain popularity by endowing crown jewels to religious places and his subordinates.

In general, we may conclude that aside from the known and determining internal and foreign factors, there were other factors such as crown jewels which played a significant role, although they have been less noticed by researchers.

\section{References}

Abbasi, M. R., Badi'i, P. (1372). Nasir-udin Shah, the King of the Roads. Iranian National Document Organization.

Astarabadi, M. M. (1346). In H. Eshraqi (Ed.), bSultani History (From Sheikh Safi to Shah Safi). Elmi Publications, Tehran.

Beykbayat, O. (1338). In M. Rajabnia, Iranian Don Juan. Agency for Book Translation and Publication, Tehran.

Dehbashi, A. (1387). The Travel Book of Shirley Brothers. Negah Publications, Tehran. 
Della, V. P. (1384). In Sh. Shafa, Travels in Persia. Cultural and Scientific Publication Company, Tehran.

Falsafi, N. (1344). The Life of Shah Abbas I. Tehran University, Tehran.

Figueroa, D. G. (1363). Travels. (Q. Sami'i, Trans). Nashr-e No, Tehran.

Herbert, T. (1928). Travels in Persia, 1627-29 (S. 72). London.

Matthee, R. P. (1387). In H. Zandyieh, The Politics of Trade in Safavid Iran. Hawzah \& Daneshgah Research Center.

Monajjem, M. J. (1366). Abbasi History (Molla Jalal Newspaper). Vahid Publications, Bija.

Navaii, A. (1366). In S. Vahidnia (Ed), The Collection of Shah Abbas' Historical Documents and Correspondences. Zarrin, Tehran.

Nuri, A. (1369). The Itinerary of Tavernier. Sanaii Library Publications and Taiid Bookship, Isfahan.

Qomi, Q. A. Sh. H. (1383). In E. Eshraqi (Ed.), Kholas-al Tavarikh. Tehran University.

Shamlu, V. Q. (1371). In S. H. S. Naser (Ed.), Qesas-ul Khaqani. Ministry of Islamic Culture and Guidance Publications, Tehran.

Sotoodeh, M. (1383). The Jesuit Fathers' Documents. Miras-e Maktoob, Tehran.

Tafazzoli, T. (1346). The Itinerary of Sanson. Ziba Publishing House, Tehran.

Turkaman, E. B. (1382). In I. Afshar (Ed.), Alam Aray-e Abbasi History. Amir Kabir, Tehran. 